\title{
The Relationship between Metabolic Syndrome Risk Factors and High Sensitive C-reactive Protein in Abdominal Obesity Elderly Women
}

Kyung-A Shin

Department of Clinical Laboratory Science, Shinsung University, Dangjin, Korea

\section{복부비만 고령여성의 대사증후군 위험요인과 고감도 C-반응성 단백의 관련성}

신경아

신성대학교 임상병리과

High sensitive C-reactive protein (hs-CRP) has been associated with metabolic syndrome (MetS) and its risk factors. This study aimed to evaluate the association between hs-CRP and the risk factors of MetS in elderly women with abdominal obesity. The diagnosis of MetS followed the $\mathrm{AHA} / \mathrm{NHLBI}$ criteria, and abdominal obesity was defined using the WHO Asian-Pacific criteria. We used the data from 174 elderly women, with an average age of 74 years. They were classified into two groups: The absent group ( $\mathrm{N}=97)$ and the MetS group $(\mathrm{N}=77)$. Hs-CRP was significantly higher in the MetS group ( $p=0.007)$. Hs-CRP had a positive correlation with abdominal obesity $(r=0.190$, $p=0.014)$ and fasting blood glucose $(r=0.240, p=0.002)$, while having a negative correlation with $\mathrm{HDL}$ cholesterol $(r=-0.164, p=0.035)$. Moreover, hs-CRP was higher in the group with risk of high fasting blood glucose $(p=0.006)$ and low HDL-cholesterol $(p=0.010)$, even in elderly women with abdominal obesity.

Key words: Metabolic syndrome, C-reactive protein, Abdominal obesity

This is an Open Access article distributed under the terms of the Creative Commons Attribution Non-Commercial License (http://creativecommons.org/licenses/by-nc/4.0) which permits unrestricted non-commercial use, distribution, and reproduction in any medium, provided the original work is properly cited.

Copyright (C) 2017 The Korean Society for Clinical Laboratory Science. All rights reserved.

Corresponding author: Kyung-A Shin Department of Clinical Laboratory Science, Shinsung University, 1 Daehak-ro, Jeongmi-myeon, Dangjin 31801, Korea Tel: 82-41-350-1408 Fax: 82-41-350-1355 E-mail: mobitz2@hanmail.net

Received: April 20, 2017 Revised $1^{\text {st: }}$ May 11, 2017 Revised 2 ${ }^{\text {nd }}:$ May 11, 2017 Accepted: May 16, 2017
서 론

고감도 C-반응성 단백(high sensitivity C-reactive protein, hs-CRP)은 전신 염증이나 감염이 있을 경우 체내에서 생성되 는 급성 반응성 물질(acute phase reactant)로서, IL-6 (interleukin-6), 종양괴사인자- $\alpha$ (tumor necrosis factor- $\alpha$, $\mathrm{TNF}-\alpha$ )같은 염증유발성 사이토카인의 자극에 의해 간에서 생 성된다[1,2]. hs-CRP는 죽상경화증 및 혈관내피세포 기능장애 를 반영하는 지표로서, 제 2형 당뇨병, 심혈관계 질환, 대사증후
군 및 비만과 관련이 있는 것으로 보고되고 있어 그 중요성이 부 각되고 있다[2-4]. 특히 대사증후군은 내당능장애와 인슐린저 항성, 혈압상승, 이상지질혈증, 복부비만과 같은 심혈관계 질환 을 유발하는 위험인자가 한 개인에게 복합적으로 나타나는 대 사장애로서[5], 대사증후군 발생기전에 염증반응이 중요한 역 할을 한다고 제시된다[6,7]. 노화나 유전적 요인 및 스트레스 같 은 자극은 염증유발성 사이토카인의 분비를 촉진하며, 이는 급 성 염증반응에 의한 인슐린저항성과 당뇨병을 유발한다[3]. 또 한 인슐린저항성은 간에서 hs-CRP의 합성을 촉진하는 것으로 
알려져 있다[8].

전 세계적으로 대사증후군 유병률은 증가하는 추세로 2001 년 NCEP-ATP III (National Cholesterol Education Program Adult Treatment Panel III)의 기준에 따른 국내 30세 이상 성 인의 대사증후군 유병률은 33\%이며, 남성의 대사증후군 유병 률은 50대까지 나이에 비례하여 증가하다가 70대 이후 감소하 는 경향을 보인다. 반면, 여성은 연령이 증가함에 따라 대사증후 군 유병률이 증가해 폐경기 이후 급격한 증가를 보이며, 70 대 이 후에는 남성보다 2 배 높은 $64 \%$ 의 유병률을 나타낸다[9]. 여성 은 폐경 이후 에스트로겐 감소로 복부비만과 심혈관계 위험요 인이 증가하며, 이러한 호르몬 변화는 사이토카인에 의한 염증 반응을 자극하여 hs-CRP의 상승을 유도하는 것으로 보고된다 $[10,11]$. 또한 hs-CRP는 주로 간에서 생성되지만 지방세포에 서도 분비되는 것으로 알려져 있으며, 체지방이 증가함에 따라 지방세포에서의 hs-CRP 분비량은 증가한다[12].

노화에 의해 근육량은 감소하고 체지방은 증가하는 저근육 형 비만을 동반하게 되는데, 이러한 변화는 체질량지수(body mass index, BMI)에는 영향을 미치지 않지만 대사성 질환이나 심혈관계 질환의 위험을 증가시킨다[13-15]. 더욱이 우리나라 는 인구 고령화가 급격히 진행됨에 따라 고령자의 건강문제가 커다란 이슈로 대두되고 있음에도 불구하고 고령여성의 대사증 후군 위험요인과 염증반응간의 관련성에 관한 연구는 부족한 실정이다. 이 연구에서는 복부비만을 가진 고령여성을 대상으 로 대사증후군 동반 유무에 따른 대사증후군 위험요인과 $\mathrm{hs}-\mathrm{CRP}$ 와의 관련성에 대해 알아보고자 하였다.

\section{대상 및 방법}

\section{1. 연구 대상}

이 연구의 대상자는 2013년 1월부터 2015년 12월까지 경기 지역 일개 종합병원에서 건강검진을 실시한 70세 이상 85세 이 하(평균 74 3 .4세)의 고령여성을 대상으로 하였다. 전체 대상 자 290명 중에서 본 연구에 필요한 자료에 결측치를 포함하는 40 명을 제외하고 복부비만에 해당하는 174 명을 최종 대상자로 선정하였다. 복부비만은 $\mathrm{WHO}$ 서태평양지역에서 제시한 여성의 어리둘레 $80 \mathrm{~cm}$ 이상을 기준으로 적용하였다[16]. 연구 대상자 의 약물복용에 대한 정보는 자기기입식 설문지 작성을 통해 조 사하였으며, 이 연구는 경기지역 종합병원 생명윤리 심의위원 회의 승인을 받은 후 시행되었다(IRB No: D-1617-006-0250).

\section{2. 연구방법}

1) 진단기준

대사증후군 진단은 AHA/NHLBI (American Heart Association/National Heart, Lung and Blood Institute) 2005년 의 기준에 따라 다음 5 가지 기준 중 3 개 이상 해당되는 경우 대사 증후군 진단군(MetS, $\mathrm{N}=77$ )으로 분류하였으며, 2 개 이하의 위 험요인에 해당하는 경우 대조군(Absent, N=97)으로 분류하였 다[17]. 1) 중성지방 $\geq 150 \mathrm{mg} / \mathrm{dL}$ 또는 고중성지방혈증 약 복 용 2) $\mathrm{HDL}$-콜레스테롤은 여성 $<50 \mathrm{mg} / \mathrm{dL}$ 또는 저 $\mathrm{HDL}$-콜레 스테롤혈증 약 복용 3) 혈압 $\geq 130 / 85 \mathrm{mmHg}$ 또는 고혈압 약 복용 4) 공복혈당 $\geq 100 \mathrm{mg} / \mathrm{dL}$ 또는 혈당강하제 복용 5) 허리 둘레는 여성 $\geq 88 \mathrm{~cm}$ 으로 정의하고 있으나, 아시아-태평양 기 준인 $\geq 80 \mathrm{~cm}$ 을 복부비만 기준으로 적용하였다[16].

\section{2) 신체계측 및 혈압측정}

신장과 체중은 DS-103M (Jenix, Seoul, Korea) 신장체중 자 동 측정기로 측정하였으며, $\mathrm{BMI}\left(\mathrm{kg} / \mathrm{m}^{2}\right)$ 는 몸무게 $(\mathrm{kg}) \div$ [신장 $(\mathrm{m}) \times$ 신장 $(\mathrm{m})]$ 으로 계산하였다. 허리둘레는 $\mathrm{WHO}$ 에서 제시 한 방법에 따라 25 30 cm 가량 양 발을 벌리고 숨을 내쉰 상태 로 갈비뼈 가장 아래 부위와 골반 가장 높은 위치의 중간 위치를 측정하였고, 엉덩이 둘레는 엉덩이의 가장 높은 곳을 줄자로 측 정하였다. 허리-엉덩이 둘레비율(waist to hip ratio, WHR)은 허리둘레를 엉덩이둘레로 나눈 값이며, 신장-허리둘레 비율 (waist to height ratio, WHtR)은 허리둘레를 신장으로 나눈 값 을 의미한다. 또한 수축기와이완기 혈압은 10 분 동안 안정 상태 에서 수은 혈압계로 2 회 측정하여 평균값을 제시하였다.

\section{3) 혈액검사}

혈액검사는 8시간 이상 공복상태에서 오전 중에 채혈을 실시 하였으며, TBA-200FR NEO (Toshiba, Tokyo, Japan) 생화학 분석기로 총콜레스테롤, 중성지방, HDL (high density lipoprotein)-콜레스테롤, LDL (low density lipoprotein)-콜레스 테롤, 공복혈당, 고감도 C-반응성 단백(high sensitivity C-reactive protein, hs-CRP), 요산을 측정하였다. 고감도 C-반응 성 단백은 면역비탁법(turbidimetric immunoassay, TIA)의 원리로 측정하였다. 당화혈색소(hemoglobin A1c, HbA1c)는 EDTA 전혈 검체로 Variant II (Bio Rad, CA, USA) 장비를 이용 하여 고성능액체크로마토그래피법(high performance liquid chromatography, HPLC)의 원리로 측정하였다. 또한 인슐린 은 Modular Analytics E170 (Roche, Mannheim, Germany) 
장비로 전기화학발광면역분석법(electrochemiluminescence immunoassay, ECLIA)의 원리로 검사하였다. 백혈구수는 EDTA 전혈 검체로 LH 750 (Beckman Coulter, Miami, FL, USA)를 이용하여 측정하였다.

\section{3. 통계분석}

이 연구의 통계분석은 Windows SPSS 21.0 (IBM, Armonk, USA) 프로그램을 사용하였으며, 모든 자료는 평균과 표준편차 및 빈도와\%를 제시하였다. 대사증후군 진단군과 대조군의 집 단간 인체측정학적 변인, hs-CRP와 그 외의 혈액학적 변인의 차이를 비교하기 위해 독립표본 $t$ 검증(independent $t$-test)을 실시하였으며, 대사증후군 진단군과 대조군간의 대사증후군 위험요인 빈도 차이를 비교하기 위해 카이제곱 검정(chi-square test)을 시행하였다. 또한 대사증후군 위험요인과 hs-CRP의 상 관성을 알아보기 위해 피어슨의 적률 상관분석(Pearson correlation coefficient)을 실시하였다. 본 연구자료 중 hs-CRP는 정규분포를 하지 않는 한쪽으로 편향된 분포를 보이고 있어 로 그 변환(log-transformed)하여 통계분석에 이용하였으며, 이 연구결과의 통계적 유의수준은 $p<0.05$ 로 설정하였다.

\section{결 과}

\section{1. 대사증후군 유무에 따른 인체측정학적 및 혈액학적 변인의 차이}

연구 대상자 174 명 중 대사증후군 진단군은 77 명, 대조군은 97명 이었다. 두 집단간 인체측정학적 변인인 연령, 신장, 체중, $\mathrm{BMI}$, 엉덩이 둘레, WHR, WHtR은 차이가 없었다(Table 1). 또 한 혈액학적 변인 중 총콜레스테롤, $\mathrm{HbA1c}$ 는 대조군보다 대사 증후군 진단군이 통계적으로 유의하게 높았다(각각 $p<0.001)$.

Table 1. Anthropometric parameters of study subjects according to presence of metabolic syndrome

\begin{tabular}{lccc}
\hline \multicolumn{1}{c}{ Variable } & $\begin{array}{c}\text { MetS } \\
(\mathrm{N}=77)\end{array}$ & $\begin{array}{c}\text { Absent } \\
(\mathrm{N}=97)\end{array}$ & p-value \\
\hline Age $(\mathrm{yr})$ & $74.56 \pm 3.81$ & $73.57 \pm 3.03$ & 0.058 \\
Height $(\mathrm{cm})$ & $150.68 \pm 5.31$ & $151.80 \pm 5.39$ & 0.173 \\
Weight $(\mathrm{kg})$ & $59.64 \pm 6.61$ & $60.86 \pm 6.89$ & 0.241 \\
Body mass index $\left(\mathrm{kg} / \mathrm{m}^{2}\right)$ & $26.27 \pm 2.28$ & $26.40 \pm 2.69$ & 0.741 \\
Hip circumference $(\mathrm{cm})$ & $94.81 \pm 5.00$ & $95.77 \pm 5.32$ & 0.230 \\
WHR & $0.91 \pm 0.05$ & $0.90 \pm 0.04$ & 0.145 \\
WHtR & $0.57 \pm 0.42$ & $0.57 \pm 0.43$ & 0.929 \\
\hline
\end{tabular}

Calculated by independent $t$-test.

Values are presented as mean \pm SD.

Abbreviations: MetS, metabolic syndrome; WHR, waist hip ratio; WHtR, waist height ratio.
그러나 LDL-콜레스테롤, 인슐린, 백혈구수, 요산은 집단간 차 이가 없었다(Table 2).

\section{2. 대사증후군 유무에 따른 hs-CRP의 차이}

대사증후군 존재 유무에 따른 hs-CRP의 집단간 차이를 비교 한 결과, 대조군(0.12 \pm 0.15$)$ 보다 대사증후군 진단군(0.22 \pm 0.20$)$ 의 hs-CRP가 통계적으로 유의하게 높았다( $p=0.007$ ) (Figure 1).

\section{3. 대사증후군 유무에 따른 대사증후군 위험요인 차이}

복부비만을 가진 고령여성의 대사증후군 유무에 따른 대사 증후군 위험요인의 차이를 비교한 결과, 수축기와 이완기 혈압, 중성지방, 공복혈당은 대조군보다 대사증후군 진단군이 통계

Table 2. Biochemical parameters of study subjects according to presence of metabolic syndrome

\begin{tabular}{lccc}
\hline \multicolumn{1}{c}{ Variable } & $\begin{array}{c}\text { MetS } \\
(\mathrm{N}=77)\end{array}$ & $\begin{array}{c}\text { Absent } \\
(\mathrm{N}=97)\end{array}$ & $p$-value \\
\hline $\begin{array}{c}\text { Total cholesterol } \\
(\mathrm{mg} / \mathrm{dL})\end{array}$ & $199.63 \pm 39.55$ & $195.66 \pm 35.44$ & $<0.001$ \\
$\begin{array}{l}\mathrm{LDL}-\mathrm{cholesterol} \\
(\mathrm{mg} / \mathrm{dL})\end{array}$ & $129.46 \pm 33.62$ & $120.30 \pm 32.17$ & 0.075 \\
$\mathrm{HbA} 1 \mathrm{c}(\%)$ & $6.30 \pm 0.89$ & $5.85 \pm 0.50$ & $<0.001$ \\
Insulin $(\mathrm{uU} / \mathrm{mL})$ & $7.27 \pm 4.21$ & $5.99 \pm 3.91$ & 0.198 \\
WBC $\left(\times 10^{3} \mathrm{cells} / \mu \mathrm{L}\right)$ & $6.39 \pm 1.64$ & $6.09 \pm 2.01$ & 0.285 \\
Uric acid $(\mathrm{mg} / \mathrm{dL})$ & $4.69 \pm 1.26$ & $4.45 \pm 1.15$ & 0.189 \\
\hline
\end{tabular}

Calculated by independent $t$-test.

Values are presented as mean \pm SD.

Abbreviations: MetS, metabolic syndrome; LDL, low density lipoprotein; HbA1c, hemoglobin A1c; WBC, white blood cell.

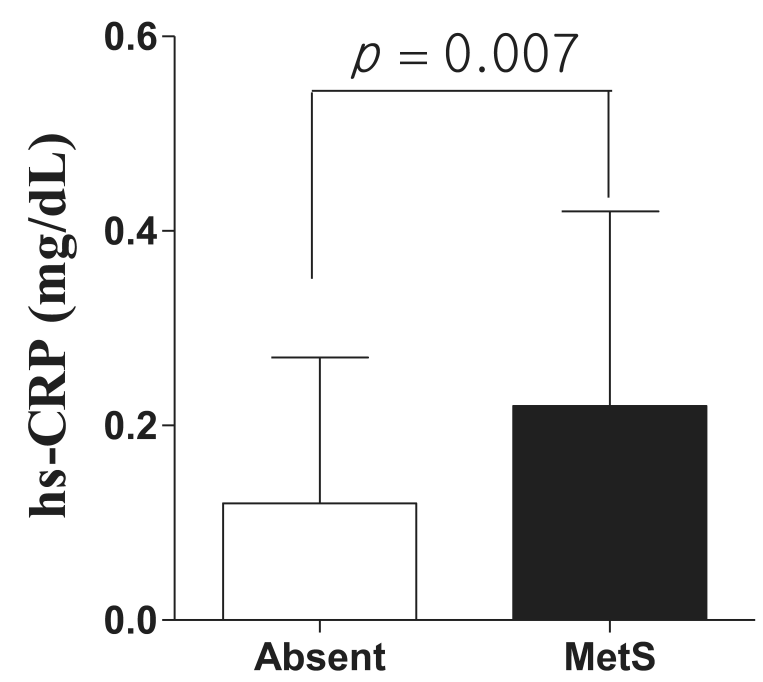

Figure 1. hs-CRP of study subjects according to presence of metabolic syndrome Absent (0.12 \pm 0.15$)$, MetS (0.22 \pm 0.20$)$. Abbreviations: hs-CRP, high sensitivity C-reactive protein. 
Table 3. Metabolic syndrome risk factors of study subjects according to presence of metabolic syndrome

\begin{tabular}{lccc}
\hline \multicolumn{1}{c}{ Variable } & MetS $(\mathrm{N}=77)$ & Absent $(\mathrm{N}=97)$ & $p$-value \\
\hline Waist circumference $(\mathrm{cm})$ & $87.01 \pm 5.89$ & $86.86 \pm 5.13$ & 0.851 \\
Systolic blood pressure $(\mathrm{mmHg})$ & $130.97 \pm 17.34$ & $115.88 \pm 11.11$ & $<0.001$ \\
Diastolic blood pressure $(\mathrm{mmHg})$ & $79.05 \pm 9.57$ & $71.60 \pm 8.05$ & $<0.001$ \\
HDL-cholesterol $(\mathrm{mg} / \mathrm{dL})$ & $46.25 \pm 11.00$ & $58.55 \pm 11.41$ & $<0.001$ \\
Triglyceride $(\mathrm{mg} / \mathrm{dL})$ & $170.51 \pm 70.80$ & $106.88 \pm 48.70$ & $<0.001$ \\
Fasting glucose $(\mathrm{mg} / \mathrm{dL})$ & $106.46 \pm 24.98$ & $92.62 \pm 14.55$ & $<0.001$ \\
High blood pressure* & $53(68.8)$ & $24(31.2)$ & $<0.001$ \\
Low HDL-cholesterol* & $57(74.0)$ & $20(26.0)$ & \\
High fasting glucose* & $38(49.4)$ & $39(50.6)$ & \\
High triglyceride* $^{*}$ & $48(62.3)$ & $29(37.7)$ & \\
\hline
\end{tabular}

Calculated by independent $t$-test.

Values are presented as mean \pm SD.

*Calculated by $\chi^{2}$-test. Data are presented as number (\%)

Abbreviations: MetS, metabolic syndrome; HDL, high density lipoprotein; LDL, low density lipoprotein.

Table 4. Correlation between metabolic syndrome risk factors and hs-CRP

\begin{tabular}{lcc}
\hline \multirow{2}{*}{ Metabolic syndrome risk factors } & \multicolumn{2}{c}{$\mathrm{hs}-\mathrm{CRP}(\mathrm{mg} / \mathrm{dL})^{\dagger}$} \\
\cline { 2 - 3 } & $r$ & $p$ \\
\hline Abdominal obesity $(\mathrm{cm})$ & 0.190 & 0.014 \\
Systolic blood pressure $(\mathrm{mmHg})$ & 0.077 & 0.138 \\
Diastolic blood pressure $(\mathrm{mmHg})$ & 0.123 & 0.111 \\
Total cholesterol $(\mathrm{mg} / \mathrm{dL})$ & 0.124 & 0.109 \\
$\mathrm{HDL}-$ cholesterol $(\mathrm{mg} / \mathrm{dL})$ & -0.164 & 0.035 \\
LDL-cholesterol $(\mathrm{mg} / \mathrm{dL})$ & 0.138 & 0.076 \\
Triglyceride $(\mathrm{mg} / \mathrm{dL})$ & 0.141 & 0.069 \\
Fasting glucose $(\mathrm{mg} / \mathrm{dL})$ & 0.240 & 0.002 \\
\hline
\end{tabular}

Calculated by Pearson correlation coefficient.

${ }^{\dagger}$ log-transformed data.

Abbreviations: hs-CRP, high sensitivity C-reactive protein $\mathrm{HDL}$, high density lipoprotein; LDL, low density lipoprotein.

적으로 유의하게 높았으나(각각 $p<0.001), \mathrm{HDL}$-콜레스테롤 은 대조군보다 대사증후군 진단군이 통계적으로 유의하게 낮았 다 $(p<0.001)$. 그러나 허리둘레는 집단간 차이가 없었다. 대사 증후군 위험요인의 발생빈도를 보면 높은 혈압, 낮은 $\mathrm{HDL}$-콜 레스테롤혈증, 고중성지방혈증은 대조군보다 대사증후군 진단 군에서 높은 빈도를 보였으나(각각 $p<0.001)$, 높은 혈당은 대 사증후군 진단군보다 대조군에서 높은 빈도를 보였다 $(p<0.001)$ (Table 3).

\section{4. 대사증후군 위험요인과 hs-CRP의 관련성}

대사증후군 위험요인과 hs-CRP의 관련성을 분석한 결과, $\mathrm{hs}-\mathrm{CRP}$ 와 $\mathrm{HDL}$-콜레스테롤은 음의 상관관계를 보였으며 ( $r=-0.164, p=0.035), \mathrm{hs}-\mathrm{CRP}$ 와 복부비만 $(r=0.190, p=0.014)$, 공복혈당 $(r=0.240, p=0.002)$ 은 양의 상관관계가 있었다. 그러 나 수축기와 이완기 혈압, 총콜레스테롤, $\mathrm{LDL}$-콜레스테롤, 중
Table 5. hs-CRP levels according to the levels of each metabolic syndrome risk factors

\begin{tabular}{ccc}
\hline \multicolumn{1}{c}{ Variable } & hs-CRP $(\mathrm{mg} / \mathrm{dL})^{\dagger}$ & $p$-value \\
\hline Blood pressure $(\mathrm{mmHg})$ & & \\
SBP $\geq 130$ or DBP $\geq 85$ & $0.20 \pm 0.37$ & 0.167 \\
SBP $<130$ or DBP $<85$ & $0.14 \pm 0.18$ & \\
Fasting glucose $(\mathrm{mg} / \mathrm{dL})$ & & \\
$\quad \geq 100$ & $0.21 \pm 0.24$ & 0.006 \\
$\quad<100$ & $0.14 \pm 0.28$ & \\
Triglyceride $(\mathrm{mg} / \mathrm{dL})$ & & \\
$\quad \geq 150$ & $0.17 \pm 0.18$ & 0.138 \\
$\quad<150$ & $0.16 \pm 0.31$ & \\
HDL-cholesterol (mg/dL) & & \\
$\quad<40$ & $0.22 \pm 0.37$ & 0.010 \\
$\quad \geq 40$ & $0.12 \pm 0.16$ & \\
\hline
\end{tabular}

Calculated by Pearson correlation coefficient.

${ }^{\dagger}$ log-transformed data.

Abbreviations: hs-CRP, high sensitivity C-reactive protein HDL, high density lipoprotein; LDL, low density lipoprotein.

성지방은 hs-CRP와 상관관계가 없는 것으로 나타났다(Table 4).

\section{5. 대사증후군 위험요인 유무에 따른 hs-CRP의 차이}

대사증후군 위험요인 중 높은 혈당 $(p=0.006)$ 과 낮은 $\mathrm{HDL}-$ 콜레스테롤혈증 $(p=0.010)$ 의 위험요인을 가진 복부비만 고령 여성에서 위험요인이 없는군보다 hs-CRP가 유의하게 높았다. 그러나 높은 혈당과 고중성지방혈증의 경우 위험요인 존재 유 무에 따른 hs-CRP의 차이는 없었다(Table 5).

\section{고 찰}

이 연구에서 복부비만의 고령여성을 대상으로 대사증후군 위험요인과 hs-CRP와의 관련성을 확인한 결과 대조군보다 대 
사증후군 진단군에서 hs-CRP 농도가 높았다. 또한 복부비만, 공복혈당, $\mathrm{HDL}$-콜레스테롤은 hs-CRP와 관련이 있는 대사증 후군 위험요인으로 나타났으며, 위험요인 중 높은 혈당과 낮은 $\mathrm{HDL}$-콜레스테롤혈증이 있는군에서 위험요인이 없는군보다 hs-CRP가 유의하게 높았다.

hs-CRP는 급성기 염증반응 물질 중 하나로 미세한 전신성 염증에 민감한 표지자이며, 죽상경화증 및 혈관내피세포 기능 이상과 같은 심혈관계 질환의 위험도 및 예후를 평가하는 지표 로 알려져 있다[2,18,19]. 한편, 대사증후군은 관상동맥질환을 포함한 심혈관계 질환의 사망률을 증가시키는 것으로 보고되 며, 그 발생 기전은 명확히 규명되지 않은 부분이 있으나 인슐린 저항성 및 비만과 관련된 염증반응이 근본적으로 제시된다 [20].

여성은 폐경기 이후에서 70세 이상 고령으로 이행하면서 에 스트로겐 감소로 인한 복부비만, 고중성지방혈증, 저 $\mathrm{HDL}$-콜 레스테롤혈증, 고 LDL-콜레스테롤혈증과 같은 대사증후군 위 험요인의 증가가 뚜렷하게 나타나며, 이는 고령여성의 심혈관 사건 발생 위험을 증가시키는 요인으로 작용한다[21]. Fröhlich 등[22]의 연구에 의하면 hs-CRP는 대사증후군 위험요인 중 $\mathrm{BMI}$, 혈압, 총콜레스테롤, 중성지방, $\mathrm{HDL}$-콜레스테롤, 공복혈 당, 요산과 상관관계를 보였으며, BMI가 hs-CRP와 가장 관련 성이 높은 지표임을 보고하였다. hs-CRP는 염증전구물질인 $\mathrm{IL}-6, \mathrm{TNF}-\alpha$ 의 자극으로 간에서 생성되지만 지방세포에서도 발현되며, 비만인 경우 지방세포에서의 hs-CRP 합성증가는 인 슐린저항성 및 지질대사에 영향을 미치게 된다[2,23,24].

이 연구에서도 복부비만 고령여성에서 hs-CRP 농도는 대사 증후군 위험요인과 밀접한 관련이 있으며, 특히 복부비만, 공복 혈당, HDL-콜레스테롤과 연관이 있음을 확인할 수 있었다. 또 한 대조군보다 대사증후군 진단군에서 hs-CRP가 증가하는 소 견을 보였다. 이는 대사증후군 위험요인의 개수가 증가할수록 $\mathrm{hs}-\mathrm{CRP}$ 는 증가하며, 복부비만은 hs-CRP와 독립적인 상관성 을 보이는 지표라는 보고와 일치하는 결과이다[22]. 복부비만 은 지방분해 촉진, 중성지방과 유리지방산 및 $\mathrm{acyl} \mathrm{CoA}$ 의 증가 를 유도하며, 아디포넥틴 발현을 억제시킴으로써 혈관 내피세 포에 염증반응을 증가시키고 혈관의 동맥경화성 손상 및 변성 을 유발한다[25-29]. 또한 남성을 대상으로 협심증 등 심혈관계 질환 위험인자를 가진 피험자뿐 아니라 위험요인이 없는 건강 한 성인에서도 hs-CRP가 심근경색의 위험을 예측할 수 있다는 연구결과가 보고되고 있다[30,31]. 그러므로 hs-CRP가 정상범 위를 유지한다 하더라도 하한치를 유지하는 것이 중요하다 할 수 있다.
Aguilar 등[32]은 대사증후군 진단군에서 hs-CRP의 상승이 동반된 경우 관상동맥질환의 위험이 상승한다고 보고하며, $\mathrm{Kim}[33]$ 은 hs-CRP 농도가 높을수록 대사증후군 발생 위험비 가 높게 나타난다고 보고하고 있어 결과를 종합해보면 대사증 후군과 hs-CRP의 관련성이 높음을 알 수 있다. 이 연구에서는 복부비만 상태일지라도 높은 혈당과 낮은 HDL-콜레스테롤혈 증의 위험요인이 있는군에서 hs-CRP가 높게 나타났으며, 이는 복부비만이 있더라도 대사증후군 위험요인의 동반 유무에 따라 염증관련 위험도가 달라짐을 의미하는 결과라 생각된다. 따라 서 고령여성에서 대사증후군의 조기 발견과 관리를 통한 예방 의 중요성이 강조되며, hs-CRP의 조절을 통해 대사증후군뿐 아니라 심혈관계 질환 예방을 위한 방법으로 체중조절이 제시 되고 있다[34]. Tchernof 등[34]은 폐경 후 비만 여성을 대상으 로 $14.5 \mathrm{~kg}$ 의 체중감량으로 $\mathrm{hs}-\mathrm{CRP}$ 가 평균 $32.3 \%$ 감소하는 결 과를 통해 체중감량이 hs-CRP 감소와 관련이 있음을 보고하였 다[35]. 복부비만을 가진 고령여성은 대사증후군에 쉽게 노출 될 수 있는 만큼 체중조절에 의한 hs-CRP 농도 조절은 대사증 후군 및 심혈관계 질환의 예방을 위한 효과적인 관리 방안이 될 수 있으리라 생각된다[12].

본 연구의 제한점은 후향적 단면연구로 인과관계를 설명하 기 어려우며, 고령여성을 대상으로 하여 연구 대상자가 충분하 지 못하였다. 또한 연구 대상자는 경기지역 일개 종합병원에서 건강검진을 시행하여 대표성이 부족하며, 결과의 확대해석에 제한이 있다. 다양한 염증관련 지표 중 이 연구에서는 hs-CRP 와 백혈구만을 평가하였으며, IL-6, TNF- $\alpha$ 등 다양한 염증관련 지표의 평가가 요구된다.

그럼에도 불구하고 복부비만 고령여성을 대상으로 한 이 연 구에서 대사증후군 위험요인을 동반한 집단에서 $\mathrm{hs}-\mathrm{CRP}$ 농도 가 높았으며, hs-CRP는 대사증후군 위험요인 중 복부비만, 공 복혈당, $\mathrm{HDL}$-콜레스테롤과 관련이 있는 것으로 나타났다.

\section{요 약}

이 연구에서는 복부비만을 가진 고령여성을 대상으로 대사 증후군 동반 유무에 따른 대사증후군 위험요인과 hs-CRP와의 관련성에 대해 알아보고자 하였다. 대사증후군 진단은 AHA/NHLBI (American Heart Association/National Heart, Lung and Blood Institute) 2005년 기준에 따라 5가지 기준 중 3 개 이상 해당되는 경우 대사증후군 진단군(MetS, N=77), 2개 이하의 위험요인에 해당하는 경우 대조군(Absent, N=97)으로 분류하였다. hs-CRP 농도는 대사증후군 위험요인과 밀접한 관 
련이 있으며, 특히 복부비만 $(r=0.190, p=0.014)$, 공복혈당 $(r=0.240, p=0.002), \mathrm{HDL}-$ 콜레스테롤 $(r=-0.164, p=0.035)$ 과 연관이 있음을 확인할 수 있었다. 또한 대조군보다 대사증후 군 진단군에서 hs-CRP가 높게 나타났으며( $p=0.007)$, 복부비 만 상태일지라도 높은 혈당 $(p=0.006)$ 과 낮은 $\mathrm{HDL}$-콜레스테롤 혈증 $(p=0.010)$ 의 위험요인이 있는군에서 $h s-C R P$ 가 높았다. 결론적으로 복부비만이 있더라도 대사증후군 위험요인의 동반 유무에 따라 염증관련 위험도가 달라짐을 알 수 있었다.

\section{Acknowledgements: None \\ Funding: None \\ Conflict of interest: None}

\section{REFERENCES}

1. Kushner I. Regulation of the acute phase response by cytokines. Perspect Biol Med. 1993;36(4):611-622.

2. Ridker PM. C-reactive protein and the prediction of cardiovascular events among those at intermediate risk: moving an inflammatory hypothesis toward consensus. J Am Coll Cardiol. 2007;49(21):2129-2138.

3. Pickup JC, Crook MA. Is type II diabetes mellitus a disease of the innate immune system? Diabetologia. 1998;41(10):1241-1248.

4. Brook RD, Bard RL, Rubenfire M, Ridker PM, Rajagopalan S. Usefulness of visceral obesity (waist/hip ratio) in predicting vascular endothelial function in healthy overweight adults. Am J Cardiol. 2001;88(11):1264-1269.

5. Reaven GM. Banting lecture 1988. Role of insulin resistance in human disease. Diabetes. 1988;37(12):1595-1607.

6. Yudkin JS, Kumari M, Humphries SE, Mohamed-Ali V. Inflammation, obesity, stress and coronary heart disease: is interleukin-6 the link? Atherosclerosis. 2000;148(2):209-214.

7. de Ferranti S, Rifai N. C-reactive protein and cardiovascular disease: a review of risk prediction and interventions. Clin Chim Acta. 2002;317(1-2):1-15.

8. Campos SP, Baumann H. Insulin is a prominent modulator of the cytokine-stimulated expression of acute-phase plasma protein genes. Mol Cell Biol. 1992;12(4):1789-1797.

9. Lym YL, Hwang SW, Shim HJ, Oh EH, Chang YS, Cho BL. Prevalence and risk factors of the metabolic syndrome as defined by NCEP-ATP III. J Korean Acad Fam Med. 2003;24(2): 135-143.

10. Park JS, Kim YJ, Lee JG, Kim YJ, Lee S, Min HG, et al. The role of $\mathrm{C}$-reactive protein as a inflammation-related factor in metabolic syndrome. Korean J Fam Med. 2009;30(6):449-456.

11. Ford ES. Body mass index, diabetes, and C-reactive protein among U.S. adults. Diabetes Care. 1999;22(12):1971-1977.

12. Pannacciulli N, Cantatore FP, Minenna A, Bellacicco M, Giorgino R, De Pergola G. C-reactive protein is independently associated with total body fat, central fat, and insulin resistance in adult women. Int J Obes Relat Metab Disord. 2001;25(10):
1416-1420.

13. Poirier P, Giles TD, Bray GA, Hong Y, Stern JS, Pi-Sunyer FX, et al. Obesity and cardiovascular disease: pathophysiology, evaluation, and effect of weight loss: an update of the 1997 American Heart Association Scientific Statement on Obesity and Heart Disease from the Obesity Committee of the Council on Nutrition, Physical Activity, and Metabolism. Circulation. 2006;113(6):898-918.

14. Aubertin-Leheudre M, Lord C, Goulet ED, Khalil A, Dionne IJ. Effect of sarcopenia on cardiovascular disease risk factors in obese postmenopausal women. Obesity (Silver Spring). 2006; 14(12):2277-2283.

15. Baumgartner RN, Wayne SJ, Waters DL, Janssen I, Gallagher D, Morley JE. Sarcopenic obesity predicts instrumental activities of daily living disability in the elderly. Obes Res. 2004;12(12): 1995-2004.

16. World Health Organization. The Asia-Pacific Perspective: Redefining obesity and its treatment. Sydney, Australia: Health Communications Australia; 2000. p19-20.

17. Grundy SM, Cleeman JI, Daniels SR, Donato KA, Eckel RH, Franklin BA, et al. Diagnosis and management of the metabolic syndrome: an American Heart Association/National Heart, Lung, and Blood Institute scientific statement. Crit Pathw Cardiol. 2005;4(4):198-203.

18. Tracy RP, Lemaitre RN, Psaty BM, Ives DG, Evans RW, Cushman $\mathrm{M}$, et al. Relationship of C-reactive protein to risk of cardiovascular disease in the elderly. Results from the cardiovascular health study and the rural health promotion project. Arterioscler Thromb Vasc Biol. 1997;17(6):1121-1127.

19. Koenig W, Sund M, Fröhlich M, Fischer HG, Löwel H, Döring A, et al. C-Reactive protein, a sensitive marker of inflammation, predicts future risk of coronary heart disease in initially healthy middle-aged men: results from the MONICA (Monitoring Trends and Determinants in Cardiovascular Disease) Augsburg Cohort Study, 1984 to 1992. Circulation. 1999;99(2):237-242.

20. Kim MK, Park JH. Metabolic syndrome. J Korean Med Assoc. 2012;55(10):1005-1013.

21. Lovejoy JC. The menopause and obesity. Prim Care. 2003; 30(2):317-325

22. Fröhlich M, Imhof A, Berg G, Hutchinson WL, Pepys MB, Boeing $\mathrm{H}$, et al. Association between $\mathrm{C}$-reactive protein and features of the metabolic syndrome: a population-based study. Diabetes Care. 2000;23(12):1835-1839.

23. Danesh J, Whincup P, Walker M, Lennon L, Thomson A, Appleby $\mathrm{P}$, et al. Low grade inflammation and coronary heart disease: prospective study and updated meta-analyses. BMJ. 2000;321(7255):199-204.

24. Yudkin JS, Stehouwer CD, Emeis JJ, Coppack SW. C-reactive protein in healthy subjects: associations with obesity, insulin resistance, and endothelial dysfunction: a potential role for cytokines originating from adipose tissue? Arterioscler Thromb Vasc Biol. 1999;19(4):972-978.

25. Yamauchi T, Kamon J, Waki H, Terauchi Y, Kubota N, Hara K, et al. The fat-derived hormone adiponectin reverses insulin resistance associated with both lipoatrophy and obesity. Nat Med. 2001;7(8):941-946.

26. Hotta K, Funahashi T, Arita Y, Takahashi M, Matsuda M, 
Okamoto Y, et al. Plasma concentrations of a novel, adiposespecific protein, adiponectin, in type 2 diabetic patients. Arterioscler Thromb Vasc Biol. 2000;20(6):1595-1599.

27. Yang WS, Lee WJ, Funahashi T, Tanaka S, Matsuzawa Y, Chao $\mathrm{CL}$, et al. Weight reduction increases plasma levels of an adipose-derived anti-inflammatory protein, adiponectin. J Clin Endocrinol Metab. 2001;86(8):3815-3819.

28. Ouchi N, Kihara S, Arita Y, Nishida M, Matsuyama A, Okamoto $\mathrm{Y}$, et al. Adipocyte-derived plasma protein, adiponectin, suppresses lipid accumulation and class A scavenger receptor expression in human monocyte-derived macrophages. Circulation. 2001;103(8):1057-1063.

29. Okamoto Y, Arita Y, Nishida M, Muraguchi M, Ouchi N, Takahashi M, et al. An adipocyte-derived plasma protein, adiponectin, adheres to injured vascular walls. Horm Metab Res. 2000;32(2):47-50.

30. Kuller LH, Tracy RP, Shaten J, Meilahn EN. Relation of C-reactive protein and coronary heart disease in the MRFIT nested case-control study. Multiple Risk Factor Intervention Trial. Am J
Epidemiol. 1996;144(6):537-547.

31. Ridker PM, Cushman M, Stampfer MJ, Tracy RP, Hennekens CH. Inflammation, aspirin, and the risk of cardiovascular disease in apparently healthy men. N Engl J Med. 1997;336(14):973-979.

32. Aguilar D, Fisher MR, O'Connor CM, Dunne MW, Muhlestein JB, Yao L, et al. Metabolic syndrome, C-reactive protein, and prognosis in patients with established coronary artery disease. Am Heart J. 2006;152(2):298-304.

33. Kim JI. The Association between hs-CRP Concentration of Blood and Metabolic Syndrome in the Residents of a Rural Community. Korean J Community Nutr. 2010;15(6):796-805.

34. Tchernof A, Nolan A, Sites CK, Ades PA, Poehlman ET. Weight loss reduces C-reactive protein levels in obese postmenopausal women. Circulation. 2002;105(5):564-569.

35. Laimer M, Ebenbichler CF, Kaser S, Sandhofer A, Weiss H, Nehoda H, et al. Markers of chronic inflammation and obesity: a prospective study on the reversibility of this association in middle-aged women undergoing weight loss by surgical intervention. Int J Obes Relat Metab Disord. 2002;26(5):659- 662. 